\title{
The Effect of Mn and Si on the Properties of Advanced High Strength Steels Processed by Quenching and Partitioning
}

\author{
Mašek Bohuslav ${ }^{1, a}$, Jirková Hana ${ }^{1, b}$, Hauserová Daniela ${ }^{2, c}$, \\ Kučerová Ludmila ${ }^{1, d}$, Klauberová Danuše ${ }^{1, e}$ \\ ${ }^{1}$ University of West Bohemia in Pilsen, Research Centre of Forming Technology, \\ Univerzitní 22, CZ - 30614 Pilsen, Czech Republic \\ ${ }^{2}$ COMTES FHT a.s., Průmyslová 995, CZ - 33441 Dobřany, Czech Republic \\ amasekb@vctt.zcu.cz, ${ }^{b}$ hstankov@vctt.zcu.cz, ${ }^{c}$ daniela.hauserova@comtesfht.cz, \\ dskal@vctt.zcu.cz, ed.klauberova@vctt.zcu.cz
}

\begin{abstract}
Keywords: Q-P process, high strength steel, heat and thermomechanical treatment, retained austenite
\end{abstract}

\begin{abstract}
The concepts new types of materials are, for economic reasons, focused mainly on low alloyed steels with a good combination of strength and ductility. Suitable heat and thermomechanical treatments play an important role for the utilization of these materials. Different alloying strategies are used to influence phase transformations. The quenching and partitioning process (Q-P Process) is one of the heat treatment methods which can result in a high ultimate strength as well as a good ductility. However, these good properties can be obtained only if a sufficient amount of retained austenite is stabilized. The influence of different contents of manganese, silicon and chromium on microstructural development and mechanical properties were experimentally tested. Alloying elements were used to stabilize the retained austenite in the final microstructure and also to strengthen the solid solution. Ultimate strengths of over $2000 \mathrm{MPa}$ with ductility over $10 \%$ were reached after the optimization of the Q-P Process. The microstructures were analyzed using several microscopic methods; mechanical properties were determined by a tensile test and the volume fraction of the retained austenite was established by X-ray diffraction phase analysis.
\end{abstract}

\section{Introduction}

Innovative Q-P process is a progressive heat treatment for steel which is differentiated from standard quenching and tempering by the fact that during low-temperature tempering supersaturated tetragonal martensite transforms to cubic martensite with synchronous precipitation of carbides. This transformation of martensite occurs during Q-P process as well; however, excessive carbon diffuses from the supersaturated martensite into the untransformed austenite. Carbide precipitation is in this case suppressed by using a suitable alloying strategy and heat treatment conditions. Retained austenite saturated with carbon remains stable even at room temperature and the final microstructure is composed of martensite and stabilized retained austenite. The fraction of retained austenite depends on several factors which are closely related. It is mainly the lowest undercooling temperature, the temperature of stabilization of untransformed austenite and also the hold at this temperature. The optimal parameters of the process depend strongly on the chemical composition of the steel [1].

\section{Experimental Procedures}

For the Q-P process it is important not only to keep to the exact parameters of the process, but also to choose the most efficient alloying strategy. Alloying elements have to hinder carbide precipitation during martensite tempering, stabilise retained austenite at room temperature and strengthen solid solution so that high ultimate strength with good ductility can be achieved. This is the reason why chromium, manganese and silicon were chosen as the main alloying elements besides carbon. 
Manganese and silicon play an important role in transformation kinetics and retained austenite stabilisation. Silicon as an element insoluble in cementite prevents or hinders carbide precipitation and thus enables diffusion of carbon into retained austenite [2]. Manganese as an austenite stabilizer, increases solubility of carbon in austenite and opens cooling area by hindering pearlite formation. Both manganese and silicon also increase the strength of material by solid solution strengthening [3]. Chromium increases stability and slows down pearlitic and bainitic transformation, increases strength and quench-ability of low alloyed steels.

Three melts were designed to establish the influence of silicon and manganese contents on microstructure development and properties (Table 1). The first melt was designated $\mathrm{H} 0$ and the next two modifications $\mathrm{H} 1$ and $\mathrm{H} 2$. Both modifications had a higher silicon content and $\mathrm{H} 2$ also had a higher manganese content. The ingots were forged into bar semi products from which specimens for thermo-mechanical processing were made.

Table 1 Chemical composition of experimental materials [wt.\%]

\begin{tabular}{|l|l|l|l|l|l|l|l|l|l|l|l|l|}
\hline Melt & $\mathrm{C}$ & $\mathrm{Si}$ & $\mathrm{Mn}$ & $\mathrm{Cr}$ & $\mathrm{Mo}$ & $\mathrm{Al}$ & $\mathrm{Nb}$ & $\mathrm{P}$ & $\mathrm{S}$ & $\mathrm{Ni}$ & $\mathrm{Cu}$ & $\mathrm{Sn}$ \\
\hline $\mathrm{H} 0$ & 0.43 & 2.03 & 0.59 & 1.33 & 0.03 & 0.008 & 0.03 & 0.009 & 0.004 & 0.07 & 0.07 & 0.01 \\
\hline $\mathrm{H} 1$ & 0.43 & 2.6 & 0.59 & 1.33 & 0.03 & 0.008 & 0.03 & 0.01 & 0.01 & 0.01 & 0.07 & 0.01 \\
\hline $\mathrm{H} 2$ & 0.43 & 2.6 & 1.17 & 1.33 & 0.03 & 0.008 & 0.03 & 0.01 & 0.011 & 0.07 & 0.07 & 0.01 \\
\hline
\end{tabular}

\section{Determination of phase transformation} temperature. In order to design heat and thermomechanical treatment properly it is necessary to know the temperatures of individual phase transformations. For the Q-P process the temperature of the beginning of martensitic transformation, $\mathrm{M}_{\mathrm{s}}$ is of the utmost importance. This is why CCT diagrams were calculated for experimental material using JMatPro software.

For the $\mathrm{H} 0$ melt $\mathrm{M}_{\mathrm{s}}=298^{\circ} \mathrm{C}$ was established and the temperature of ferrite formation was $822^{\circ} \mathrm{C}$. The higher silicon content of the $\mathrm{H} 1$ melt resulted in the increase of $\mathrm{Ar}_{3}$ temperature to $857^{\circ} \mathrm{C}$ and also in the shift of transformation temperatures to faster cooling rates (Fig. 1). $M_{s}$ temperature simultaneously increased to $309^{\circ} \mathrm{C}$. With regard to the higher manganese content in the $\mathrm{H} 2$ melt, $\mathrm{A}_{\mathrm{r} 3}$ temperature decreased slightly to $835^{\circ} \mathrm{C}$ and transformation temperatures also shifted toward slower cooling rates. In comparison with $\mathrm{H} 0$ and $\mathrm{H} 1$ melts, $\mathrm{M}_{\mathrm{s}}$ temperature dropped more markedly to $276^{\circ} \mathrm{C}$.

Original state of material. The original state of the material was documented on forged bars and evaluated by metallographic analysis. The microstructure was pearlitic-ferritic in all three materials with approximately $15 \%$ ferrite (Fig. 2).

Thermomechanical simulator. The concept and

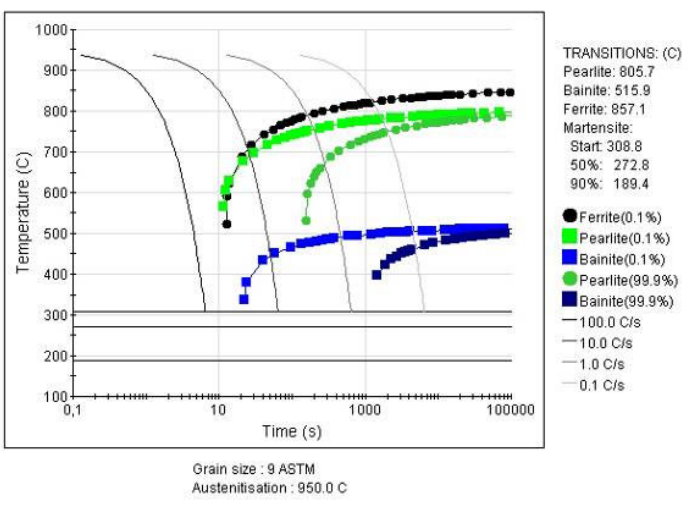

Fig. 1: CCT diagram for experimental material $\mathrm{H} 1$

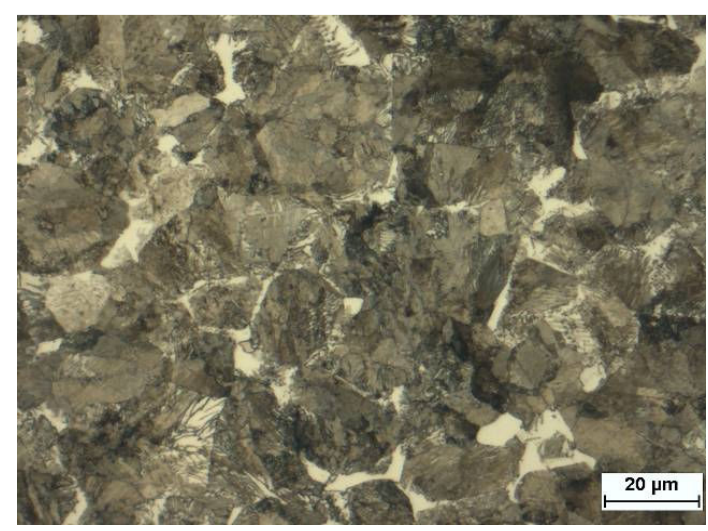

Fig. 2: Steel HO - pearlitic-ferritic structure of original state optimisation of a new type of processing strategy must precisely control temperature and deformation development during processing. The samples were therefore processed by thermomechanical simulator. A unique controlling system of the simulator enables to execute very quick changes in temperature and deformation parameters and so simulate very precisely real processing conditions. It is possible to achieve controlled temperature gradients of $100^{\circ} \mathrm{C} / \mathrm{s}$ during heating and $250^{\circ} \mathrm{C} / \mathrm{s}$ during cooling for steels. The deformation member can reach the speeds of up to $3 \mathrm{~m} / \mathrm{s}$ and 
the process is monitored all the time. To obtain desired microstructure and properties it is necessary to optimize many processing parameters. This article focuses on the choice of the most convenient austenitization temperature and the temperature of annealing hold for carbon partitioning.

\section{Results and Discussion}

Austenization temperature. To acquire suitable final microstructure and properties, austenization temperature must be chosen so, that full austenization of the microstructure is ensured at the lowest temperature possible.

This is the reason why austenization temperatures of experimental steels were optimized in the first step. The proposed temperatures derived from the results calculated in JMatPro. Six different austenization temperatures were chosen: $885,900,915,930,940$ and $950^{\circ} \mathrm{C}$. The specimens were austenized and immediately quenched into the water. Martensitic microstructure without free ferrite was obtained in $\mathrm{H} 0$ and $\mathrm{H} 2$ steels after all tested temperatures. However the microstructure of $\mathrm{H} 1$ steel quenched from 885 and $900^{\circ} \mathrm{C}$ was martensitic with small fraction of free ferrite (Fig. 3). Quenching from temperature of $950^{\circ} \mathrm{C}$ and higher resulted in purely martensitic microstructure. Even the highest austenization temperature of $950^{\circ} \mathrm{C}$ did not cause coarsening of martensitic microstructure.

Q-P Process. Thermo-mechanical treatment strategies were designed for each experimental material on the base of previously mentioned results. Austenization temperature of $900^{\circ} \mathrm{C} / 100 \mathrm{~s}$ was chosen for material $\mathrm{H} 0$ and $950^{\circ} \mathrm{C} / 100$ s for materials $\mathrm{H} 1$ a $\mathrm{H} 2$. After austenitization followed incremental deformation

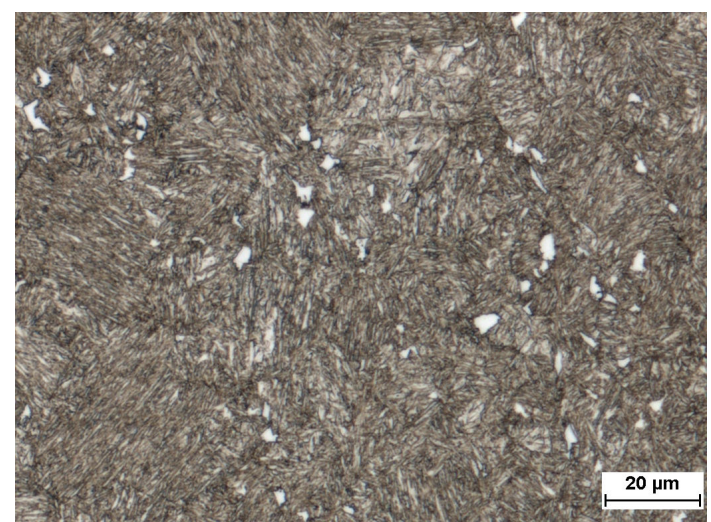

Fig. 4: H1 - martensitic microstructure with $19 \%$ of RA after TMT, $950^{\circ} \mathrm{C} / 100 \mathrm{~s}-200^{\circ} \mathrm{C} / 10 \mathrm{~s}-300^{\circ} \mathrm{C} / 600 \mathrm{~s}$ with true strain $\varepsilon=5$, which was applied in twenty steps in temperature interval of $900-820^{\circ} \mathrm{C}$. The samples were then cooled to $200^{\circ} \mathrm{C}$ where $10 \mathrm{~s}$ hold took place. In the next step were specimens heated to the isothermal hold temperature of $250^{\circ} \mathrm{C}, 300^{\circ} \mathrm{C}$ or $350^{\circ} \mathrm{C}$. Diffusion partition of carbon and thus stabilisation of retained austenite occurred during this hold.

The aim of this part of experiment was to determine the impact of isothermal hold temperature on stabilisation of retained austenite. Considering different $\mathrm{M}_{\mathrm{s}}$ temperature of each material it was also possible to analyse the influence of different manganese and silicon content on final microstructure.

First of all, processing strategy with isothermal hold of $250^{\circ} \mathrm{C}$ was carried out. Resulting microstructure for material $\mathrm{H} 0$ was martensitic with $17 \%$ of retained austenite and hardness of 546 HV10. Ultimate strength was higher than $2000 \mathrm{MPa}$ while maintaining ductility $\mathrm{A}_{5 \mathrm{~mm}}=12 \%$ (Table 2). The same type of microstructure was found in material $\mathrm{H} 2$, only hardness values reached 644 HV10. Different microstructure was observed in material H1, where larger amount of free ferrite was found in tempered base microstructure.

Elevation of isothermal hold temperature to $300^{\circ} \mathrm{C}$ produced martensitic microstructures in all three materials. The hardness of material H0 dropped from $546 \mathrm{HV} 10$ to $508 \mathrm{HV} 10$ with small decline in retained austenite fraction. Significant drop in hardness occurred also in material H2, were hardness decreased from $644 \mathrm{HV} 10$ to $566 \mathrm{HV} 10$. Increasing isothermal hold temperature had 
small effect on material $\mathrm{H} 1$, where the fraction of retained austenite increased but without marked effect on hardness values (Fig. 4).

Further enhancement of isothermal hold temperature means already to exceed $\mathrm{M}_{\mathrm{s}}$ for all three researched materials. This temperature caused higher tempering of microstructure and therefore also decline in hardness values. It was found out, that the increase of isothermal hold temperature resulted for material $\mathrm{H} 0$ in the drop of ultimate strength by $300 \mathrm{MPa}$ with simultaneous increase of ductility by $10 \%$ (Table 2). Very surprising was the increase of retained austenite fraction over $20 \%$ in material $\mathrm{H} 1$, while hardness values decreased only slightly. This interesting phenomenon will undergo further analysis.

Table 2 Results of thermo-mechanical processing

\begin{tabular}{|c|c|c|c|c|c|c|c|c|}
\hline Material & Processing & $\begin{array}{l}\text { Isothermal hold } \\
\text { temperature }\left[{ }^{\circ} \mathrm{C}\right]\end{array}$ & $\begin{array}{l}\mathrm{M}_{\mathrm{s}} \\
{\left[{ }^{\circ} \mathrm{C}\right]}\end{array}$ & $\begin{array}{l}\text { RA } \\
{[\%]}\end{array}$ & HV 10 & $\begin{array}{c}\mathrm{R}_{\mathrm{p} 0,2} \\
{[\mathrm{MPa}]}\end{array}$ & $\begin{array}{c}\mathrm{R}_{\mathrm{m}} \\
{[\mathrm{MPa}]}\end{array}$ & $\begin{array}{c}\mathrm{A}_{5 \mathrm{~mm}} \\
{[\%]}\end{array}$ \\
\hline \multirow{3}{*}{ H0 } & \multirow{3}{*}{$\begin{array}{c}900^{\circ} \mathrm{C} / 100 \mathrm{~s} \\
-200^{\circ} \mathrm{C} / 10 \mathrm{~s}\end{array}$} & 250 & \multirow{3}{*}{298} & 17 & 546 & 2087 & 2096 & 12 \\
\hline & & 300 & & 14 & 508 & 1549 & 1810 & 20 \\
\hline & & 350 & & 17 & 501 & 1652 & 1703 & 23 \\
\hline \multirow{3}{*}{ H1 } & \multirow{6}{*}{$\begin{array}{l}950^{\circ} \mathrm{C} / 100 \mathrm{~s} \\
-200^{\circ} \mathrm{C} / 10 \mathrm{~s}\end{array}$} & 250 & \multirow{3}{*}{309} & 13 & 570 & 1516 & 1965 & 17 \\
\hline & & 300 & & 19 & 577 & 1448 & 1757 & 24 \\
\hline & & 350 & & 22 & 558 & 1420 & 1702 & 25 \\
\hline \multirow{3}{*}{$\mathrm{H} 2$} & & 250 & \multirow{3}{*}{276} & 14 & 644 & 1656 & 2118 & 14 \\
\hline & & 300 & & 13 & 566 & 1557 & 1837 & 22 \\
\hline & & 350 & & 17 & 525 & 1221 & 1720 & 26 \\
\hline
\end{tabular}

\section{Summary}

Optimization of Q-P process on experimental steels with carbon content of $0.43 \%$, manganese content $0.59-1.17 \%$ and silicon content $2-2.6 \%$ tested the influence of austenization temperature and isothermal hold temperature on final microstructure development. Enhancement of silicon content from 2 to $2.6 \%$ caused formation of small portion of ferrite in quenched structure and also stabilisation of higher retained austenite fraction. In some variants up to $20 \%$ of austenite was stabilised. Free ferrite formation was suppressed by increased manganese content of steel. Manganese content increased to $1.17 \%$ in the case of $\mathrm{H} 2$ steel. Experiment further showed that increasing isothermal hold temperature increase overall amount of retained austenite stabilised in microstructure. On the other hand this higher temperature results in more intensive tempering of microstructure and also in significant increase of ductility. Ultimate strength over 2000MPa with ductility $\mathrm{A}_{5 \mathrm{~mm}}=12 \%$ was achieved for a low-cost steels with undemanding $\mathrm{Mn}$-Si-Cr alloying concept after application of Q-P process with isothermal hold temperature under $\mathrm{M}_{\mathrm{s}}$.

\section{Acknowledgements}

This paper includes results created within the project 1M06032 Research Centre of Forming Technology and within the project 106/09/1968 Development of New Grades of High-Strength Low-Alloyed Steels with Improved Elongation Values.

\section{Reference}

[1] D.V. Edmonds et al.: Materials Science and Engineering A Vol. 438-440 (2006), p. 25

[2] S. Ch. Baik, S. Kim, S. Jin, O. Kwon: ISIJ International Vol. 41 No. 3 (2001), p. 290

[3] W. Bleck, in: International Conference on TRIP - Aided High Strength Ferrous Alloys, edited by B. C. De Cooman Publications/Wissenschaftsverlag Mainz GmbH, Belgium (2002). 